\title{
Pertumbuhan tiga jenis ikan dan kangkung darat (Ipomoea reptans Poir) yang dipelihara dengan sistem akuaponik
}

[Growth of different strains of three fishes and water spinach (Ipomoea reptans Poir) based aquaponic]

\author{
Zahidah Hasan ${ }^{\varpi}$, Y. Andriani, Y. Dhahiyat, A. Sahidin, M. R. Rubiansyah \\ Fakultas Perikanan dan Ilmu Kelautan Universitas Padjadjaran \\ Jln. Raya Jatinangor km 21, Sumedang 45363
}

Diterima: 7 September 2016; Disetujui: 2 Mei 2017

\begin{abstract}
Abstrak
Penelitian ini bertujuan untuk menentukan pertumbuhan tiga jenis ikan (lele, nila, dan koi) yang dipelihara bersama dengan kangkung darat dalam sistem akuaponik. Penelitian dilakukan di Laboratorium Budi daya Perikanan, Ciparanje, Fakultas Perikanan dan Ilmu Kelautan Universitas Padjadjaran dari bulan Februari hingga April 2016. Metode yang digunakan dalam penelitian ini adalah metode eksperimental menggunakan rancangan acak lengkap dengan lima perlakuan dan diulang empat kali. Perlakuan A: kontrol positif, tanaman kangkung darat ditanam menggunakan tanah dan pupuk kompos; perlakuan B: kontrol negatif, tanaman kangkung darat ditanam menggunakan tanah tanpa menggunakan pupuk kompos; perlakuan C: akuaponik dengan ikan nila dan tanaman kangkung darat; perlakuan D: akuaponik dengan ikan lele dan tanaman kangkung darat, dan perlakuan E: ikan koi dan tanaman kangkung darat. Parameter yang diukur dalam penelitian ini adalah pertumbuhan bobot ikan, dan pertumbuhan kangkung yang meliputi tinggi batang, jumlah daun, dan biomassa panen serta kualitas air yang mencakup nitrat, ammonia, dan fosfat. Hasil penelitian menunjukkan bahwa pertumbuhan bobot ikan tertinggi diperoleh pada kombinasi lele dan kangkung darat dengan pertumbuhan sebesar 7,8 $\pm 1,18 \mathrm{~g}$ dan pertumbuhan tanaman kangkung tertinggi diperoleh pada pemeliharaan bersama koi yang menghasilkan biomassa sebesar $30,40 \pm 5,59 \mathrm{~g}$.
\end{abstract}

Kata penting: akuaponik, kangkung darat, koi, lele, nila

\begin{abstract}
This study aims to determine the growth of fish (Nile tilapia, North African catfish, and goldfish) which cultured along with water spinach in aquaponics system. The study was conducted at the Laboratory of Aquaculture, Ciparanje, Faculty of Fisheries and Marine Sciences, Padjadjaran University from February to April 2016. The experiment was designed using a completely randomized design with 5 treatments and 3 replicates. Treatment A: positive control, water spinach grown on soil and compost fertilizer, Treatment B: negative control, water spinach grown on soil without compost fertilizer, treatment C: aquaponics Nile tilapia and water spinach, Treatment D: aquaponics North African catfish and water spinach, and treatment E: aquaponics goldfish and water spinach. The measured parameters in this study were fish growth and water spinach growth include stem height, number of leaves, biomass as well as water quality included nitrates, ammonia and phosphates. The results showed that the highest fish growth, obtained in combination of catfish and water spinach with growth of $7.8 \pm 1.18$ grams and the highest water spinach growth obtain in koi cultured with water spinach with average biomass $30.40 \pm 5.59$ grams.
\end{abstract}

Keywords: aquaponics, catfish, goldfish, Nile tilapia, water spinach

\section{Pendahuluan}

Keterbatasan lahan yang sempit dan sumber air yang terbatas menjadi permasalahan dalam peningkatan produksi perikanan budi daya air tawar. Selain itu, permasalahan lain dalam budi daya perikanan adalah limbah sisa buangan yang dapat mencemari lingkungan perairan seperti ammonia dan fosfor hasil dekomposisi pakan terbuang (Garno 2002, Susila 2015). Menurut Fujaya

$\triangle$ Penulis korespondensi

Alamat surel:ibuzah@gmail.com
(2004), tidak semua pakan yang diberikan dimakan oleh ikan dan digunakan untuk pertumbuhan, namun $15-30 \%$ terbuang ke perairan. Selain itu pakan yang dimakan sebagian akan dikeluarkan dalam bentuk feses (Huisman 1976, Utomo et al. 2005). Pakan terbuang dan feses ikan merupakan salah satu sumber pencemar perairan pada kawasan budi daya perikanan.

Berdasarkan permasalahan tersebut harus ada inovasi teknologi budi daya ikan yang ramah 
lingkungan, hemat air, dan dapat meningkatkan produksi. Salah satu inovasi adalah mengintegrasikan budi daya perikanan dengan tanaman melalui sistem akuaponik (Diver 2006). Akuaponik merupakan salah satu teknologi budi daya yang mengombinasikan pemeliharaan ikan dengan tanaman (Nelson 2008). Sistem ini dapat menghemat penggunaan air dalam budi daya ikan sampai 97\% (ECOLIFE 2011). Akuaponik (pemeliharaan ikan dengan tanaman) lebih ramah lingkungan, karena pada sistem ini bakteri akan menurunkan konsentrasi ammonia, nitrit, dan nitrat (Djokosetiyanto et al. 2006). Pada tanaman, nitrat berfungsi sebagai nutrisi. Air yang kaya nutrisi dari wadah pemeliharaan disalurkan kepada tanaman, kemudian dimanfaatkan sebagai hara. Pemanfaatan ammonia oleh tanaman sebagai media filter biologis akan mengurangi konsentrasi racun pada media budi daya ikan (Crab et al. 2007). Teknologi akuaponik terbukti berhasil memproduksi ikan secara optimal dan diperlukan untuk mengantisipasi penurunan produksi akuakultur akibat penyusutan lahan budi daya dan penurunan kualitas perairan. Inovasi teknologi tersebut diharapkan mampu mengurangi limbah dan meningkatkan produktifitas per satuan luas lahan budi daya.

Hampir semua jenis tanaman air dan beberapa tanaman darat dapat digunakan dalam sistem akuaponik diantaranya adalah kangkung air (Ipomoea aquatica Forsk), kangkung darat (Ipomoea reptans Poir), dan selada (Lactuca sativa). Tanaman ini sebagai alternatif biofilter dapat menyerap nitrogen dalam bentuk amonium $\left(\mathrm{NH}_{4}^{+}\right)$ dan nitrat $\left(\mathrm{NO}_{3}^{-}\right)$sehingga nitrogen di air akan berkurang (Rakocy et al. 2006). Kualitas air merupakan faktor penting dalam budi daya perikanan dan akuaponik menjadi salah satu solusi dalam pemeliharaan kualitas air media budi daya. Hal tersebut sesuai dengan pernyataan Endut et al. (2009) bahwa keuntungan sistem akuaponik dibandingkan dengan sistem lain yaitu adanya biofilter oleh tumbuhan, sehingga akan menjaga kualitas air pada media budi daya ikan.

Yosmaniar (2010) menyatakan bahwa beban limbah budi daya ikan sangat bervariasi konsentrasi limbahnya, disebabkan oleh perbedaan spesies, karakteristik pakan (kandungan nutrisi, kualitas bahan baku, teknologi pakan), dan respons biologis ikan (pertumbuhan dan sintasan).

Alasan pemilihan ikan lele (Clarias gariepinus) dan nila (Oreochromis niloticus), dan ikan koi (Carassius auratus) merupakan ikan yang memiliki nilai ekonomis tinggi. Alasan lain pemilihan ikan adalah adanya perbedaan jumlah beban limbah sisa pakan dan feses yang dihasilkan oleh masing-masing ikan. Selain itu ikan lele, nila dan koi memiliki respon biologis terhadap pakan yang berbeda-beda, hal ini dapat dilihat dari perbedaan nisbah konversi pakan (Food conversion ratio $\mathrm{FCR}$ ) yang berbeda-beda.

Menurut Ihsanudin et al. (2014), ikan nila memiliki FCR 0,8-1,6, sedangkan Hastuti \& Subandiono (2014) menyatakan bahwa FCR ikan lele berkisar antara 0,96-1,12. Sementara itu mengingat ikan koi satu famili dengan ikan mas, maka nilai FCRnya dapat mengikuti nilai FCR ikan mas, yaitu berkisar antara 2,2-2,8 (Sulawesty et al. 2014). Berdasarkan perbedaan tersebut, diharapkan diperoleh kombinasi tanaman kangkung dan ikan terbaik sebagai rekomendasi untuk pembudidayaan secara massal.

Penelitian ini bertujuan untuk menentukan pertumbuhan ikan lele, nila, dan koi yang dibudidayakan bersama dengan kangkung darat dalam sistem akuaponik dan diharapkan hasil penelitian ini dapat memberikan informasi mengenai pertumbuhan ikan dengan jenis berbeda yang dipelihara dengan sistem akuaponik bersama kangkung darat. 


\section{Bahan dan metode}

Penelitian dilaksanakan pada bulan Februari - April 2016 di Laboratorium Budi daya Perikanan Ciparanje, Fakultas Perikanan dan Ilmu Kelautan Universitas Padjadjaran. Metode penelitian yang digunakan adalah metode eksperimental dengan Rancangan Acak Lengkap yang terdiri atas lima perlakuan dan empat kali ulangan. Padat tebar ikan adalah 100 ekor dengan bobot rata-rata 2,5 $\pm 0,36 \mathrm{~g}$ dan ditebar pada masing-masing kolam dengan ukuran $1 \mathrm{~m}$ x $1 \mathrm{~m}$ x 0,5 m dan ditanam lima batang kangkung darat tiap kolam dengan wadah yang berbeda. Adapun perlakuan yang digunakan dalam penelitian ini adalah :

Perlakuan A : kontrol positif, tanaman kangkung darat ditanam menggunakan tanah dan pupuk kompos.

Perlakuan B: kontrol negatif, tanaman kangkung darat ditanam menggunakan tanah tanpa menggunakan pupuk kompos.

Perlakuan C: sistem akuaponik dengan komoditas ikan nila Oreochromis niloticus (Linnaeus, 1758) dan tanaman kangkung darat.

Perlakuan D: sistem akuaponik dengan komoditas lele Clarias gariepinus (Burchell, 1822) dan tanaman kangkung darat.

Perlakuan E: sistem akuaponik dengan komoditas koi Carassius auratus (Linnaeus, 1758) dan tanaman kangkung darat.

Parameter ikan yang diukur adalah pertumbuhan bobot ikan, sedangkan parameter tanaman meliputi biomassa, pertambahan panjang batang, dan pertambahan jumlah daun. Pertambahan bobot, baik ikan maupun tanaman dihitung menggunakan persamaan (Ogunji et al. 2008) berikut:

$$
\mathrm{PM}=\mathrm{W}_{\mathrm{t}}-\mathrm{W}_{\mathrm{o}}
$$

Keterangan: $\mathrm{PM}=$ pertumbuhan, $\mathrm{W}_{\mathrm{o}}=$ bobot awal, $\mathrm{W}_{\mathrm{t}}=$ bobot akhir

Pengukuran parameter kualitas air dilakukan pada awal penelitian dan diulang setiap tujuh hari. Parameter kualitas air yang diuji meliputi nitrat, fosfat, dan ammonia dengan menggunakan alat spektorofotometer merk Genesys 20 .

\section{Hasil}

Hasil penelitian menunjukkan pertumbuhan bobot ikan lele, nila, dan koi selama penelitian memperlihatkan perbedaan yang cukup besar sebagaimana terlihat pada Tabel 1. Perlakuan D (kombinasi ikan lele dengan kangkung) menunjukkan pertambahan bobot tertinggi 7,8 $\pm 1,18 \mathrm{~g}$ dikuti perlakuan $\mathrm{C}$ kombinasi ikan nila dengan kangkung dan terendah pada perlakuan E dengan kombinasi ikan koi dengan kangkung.

Pertambahan bobot mingguan lele, nila, dan koi selama penelitian yang dihitung setiap tujuh hari sekali, menunjukkan pertumbuhan ikan lele lebih tinggi dibandingkan dengan dua ikan lainnya (Gambar 1).

Perbedaan jenis ikan mengakibatkan pertumbuhan tanaman kangkung dan bobot kangkung yang berbeda. Tinggi batang dan jumlah helai daun kangkung diperlihatkan pada Gambar 2 dan 3. Bobot kangkung terdapat pada Tabel 2.

Pada Tabel 2 terlihat produksi kangkung tertinggi diperoleh pada perlakuan $\mathrm{C}$ dengan biomassa akhir sebesar $31,31 \pm 4,90 \mathrm{~g}$ dan jumlah helai daun sebanyak 29,20 $\pm 14,86$ helai pada kombinasi E. Produksi terrendah terdapat pada perlakuan B dengan biomassa sebesar 6,00 $\pm 0,51 \mathrm{~g}$ dan jumlah daun sebanyak 9,80 $\pm 2,25$ helai yang jauh lebih rendah dibandingkan semua perlakuan akuaponik. 
Tabel 1. Pertumbuhan bobot ikan setiap perlakuan

\begin{tabular}{lcc}
\hline \multicolumn{1}{c}{ Perlakuan } & Bobot akhir ikan (g) & Pertumbuhan bobot (g) \\
\hline C (kombinasi ikan nila dengan kangkung) & 28,10 & $5,60 \pm 0,64$ \\
D (kombinasi lele dengan kangkung) & 10,20 & $7,80 \pm 1,18$ \\
E (kombinasi koi dengan kangkung) & 7,74 & $4,20 \pm 0,94$ \\
\hline
\end{tabular}

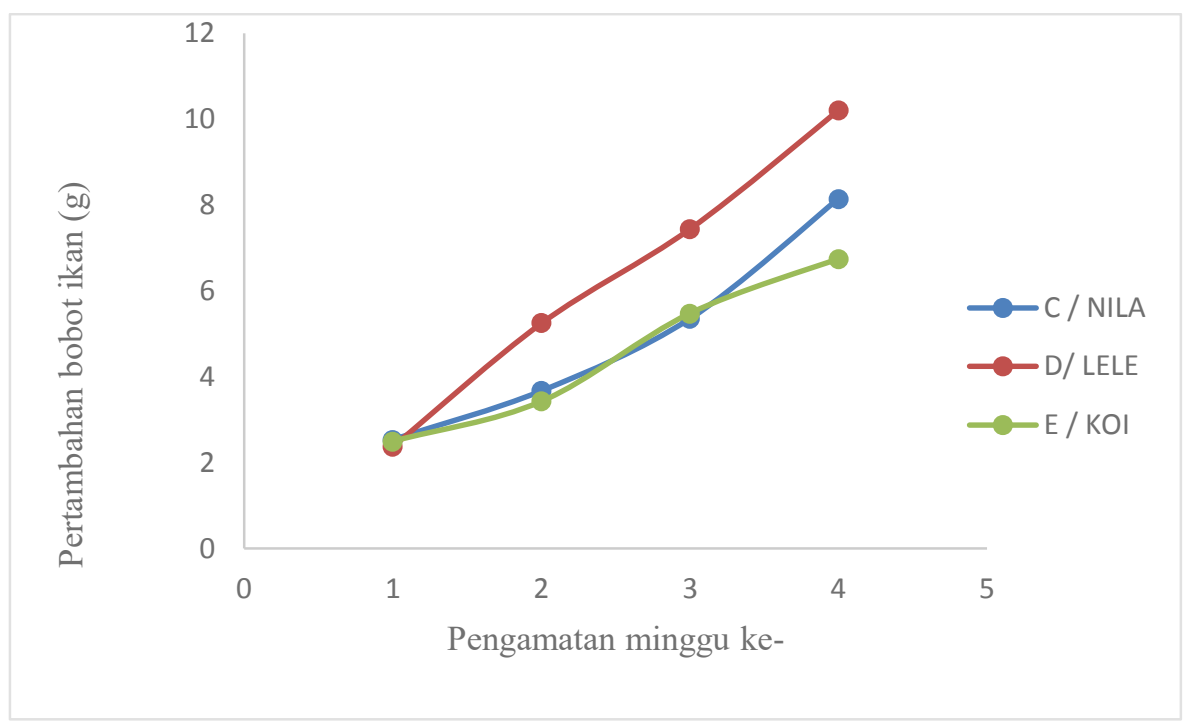

Gambar 1. Bobot ikan nila, lele dan koi setiap minggu selama penelitian

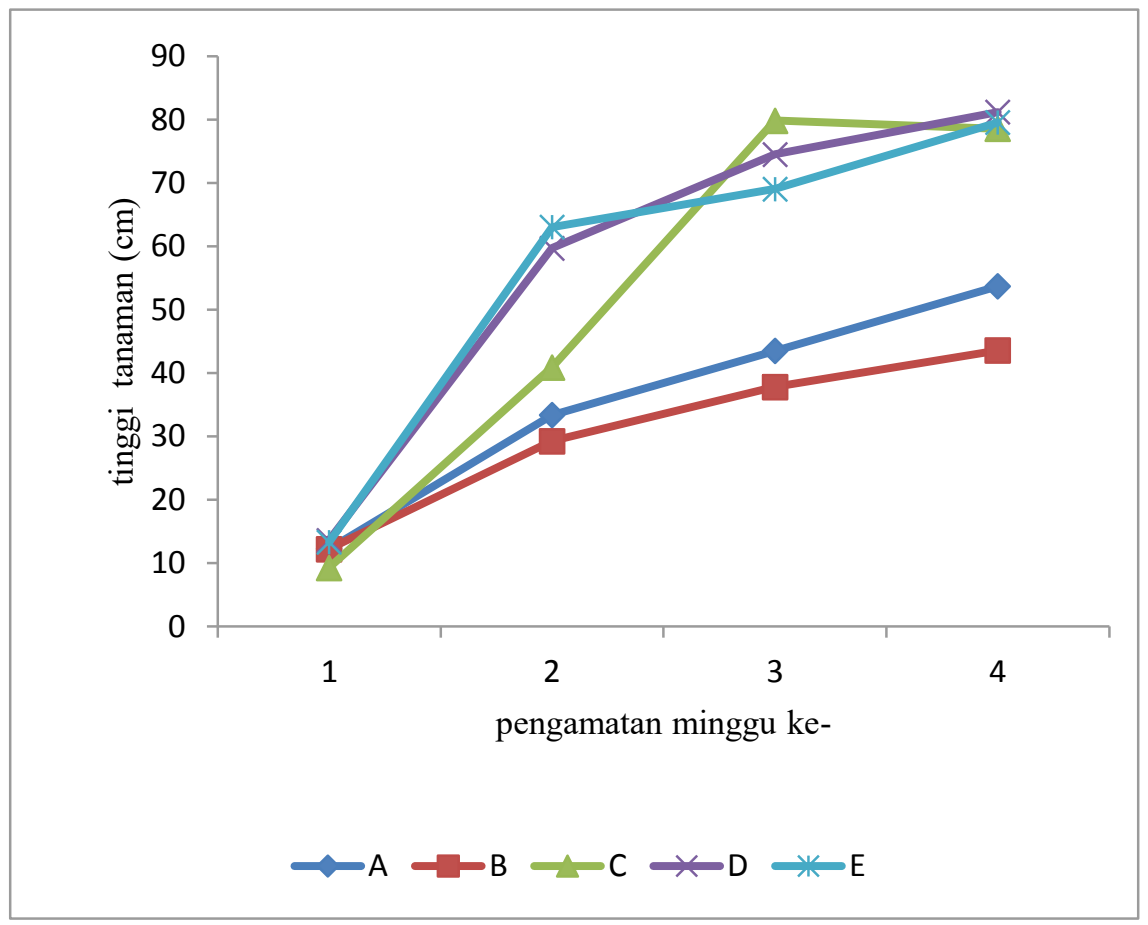

Gambar 2. Tinggi batang kangkung setiap minggu selama penelitian 


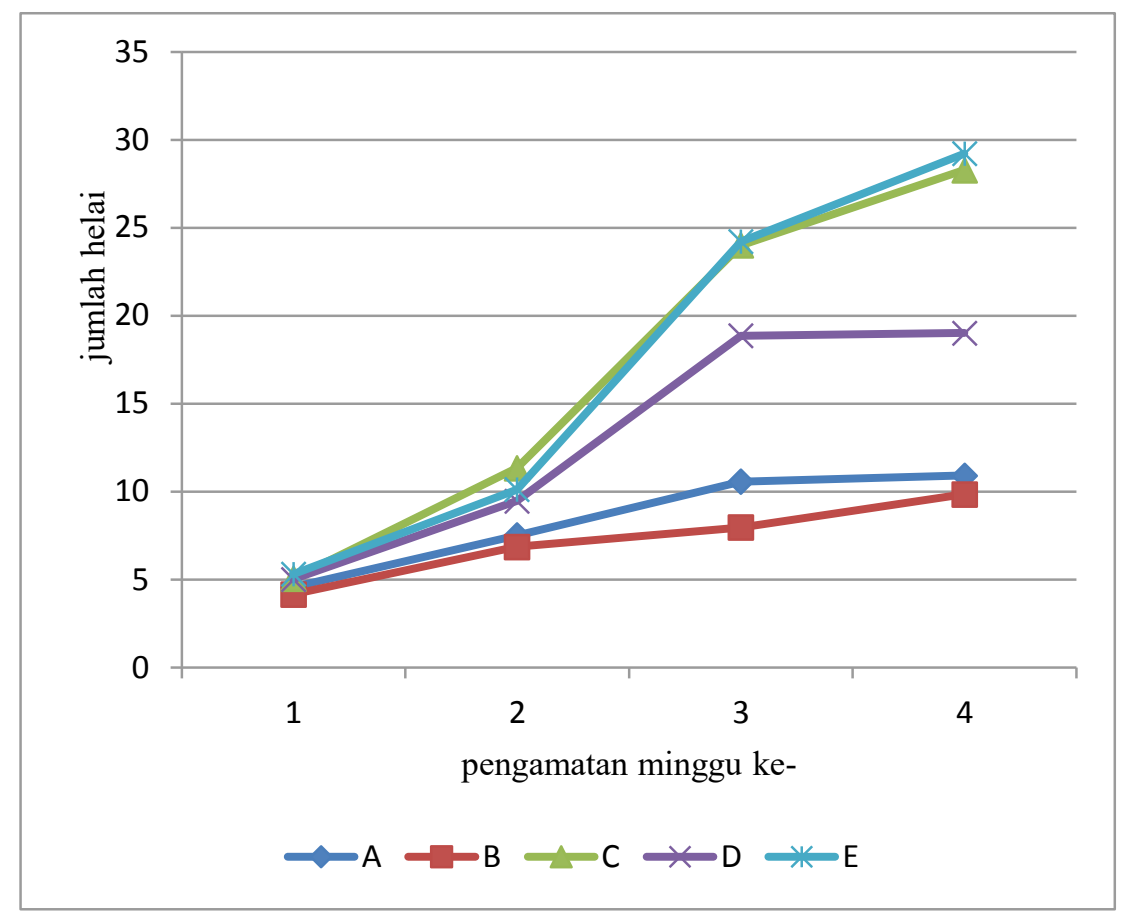

Gambar 3. Jumlah helai daun kangkung setiap minggu selama penelitian

Tabel 2. Keragaan pertumbuhan kangkung darat pada masing-masing perlakuan

\begin{tabular}{lccc}
\hline Perlakuan & Biomassa (g) & Tinggi batang $(\mathrm{cm})$ & Jumlah helai daun \\
\hline A (kontrol positif) & $8,00 \pm 2,60$ & $53,7 \pm 5,56$ & $10,9 \pm 1,23$ \\
B (kontrol negatif) & $6,00 \pm 0,51$ & $43,6 \pm 7,52$ & $9,8 \pm 2,25$ \\
C (kombinasi nila dengan kangkung) & $\mathbf{3 1 , 3 7 \pm \mathbf { 4 , 9 0 }}$ & $78,5 \pm 10,93$ & $28,3 \pm 8,61$ \\
D (kombinasi lele dengan kangkung) & $25,71 \pm 4,25$ & $\mathbf{8 1 , 1} \pm \mathbf{1 5 , 2 8}$ & $19,0 \pm 12,71$ \\
E (kombinasi koi dengan kangkung) & $30,40 \pm 5,59$ & $79,5 \pm 11,91$ & $\mathbf{2 9 , 2} \pm \mathbf{1 4 , 8 6}$ \\
\hline
\end{tabular}

Kualitas air selama peneltian ditampilkan pada Gambar 4, 5, dan 6. Gambar-gambar tersebut memperlihatkan adanya perbedaan konsentrasi nitrat, fosfat, dan ammonia antara pemeliharaan ikan nila dengan pemeliharaan ikan koi, dan pemeliharaan ikan lele.
Gambar 7 memperlihatkan panjang akar tanaman kangkung yang dipelihara pada tiga media yang berbeda (akuaponik, media kompos, dan media tanah). Akar tumbuhan kangkung pada sistem akuaponik lebih panjang dibandingkan dengan pemeliharaan media lainnya. 


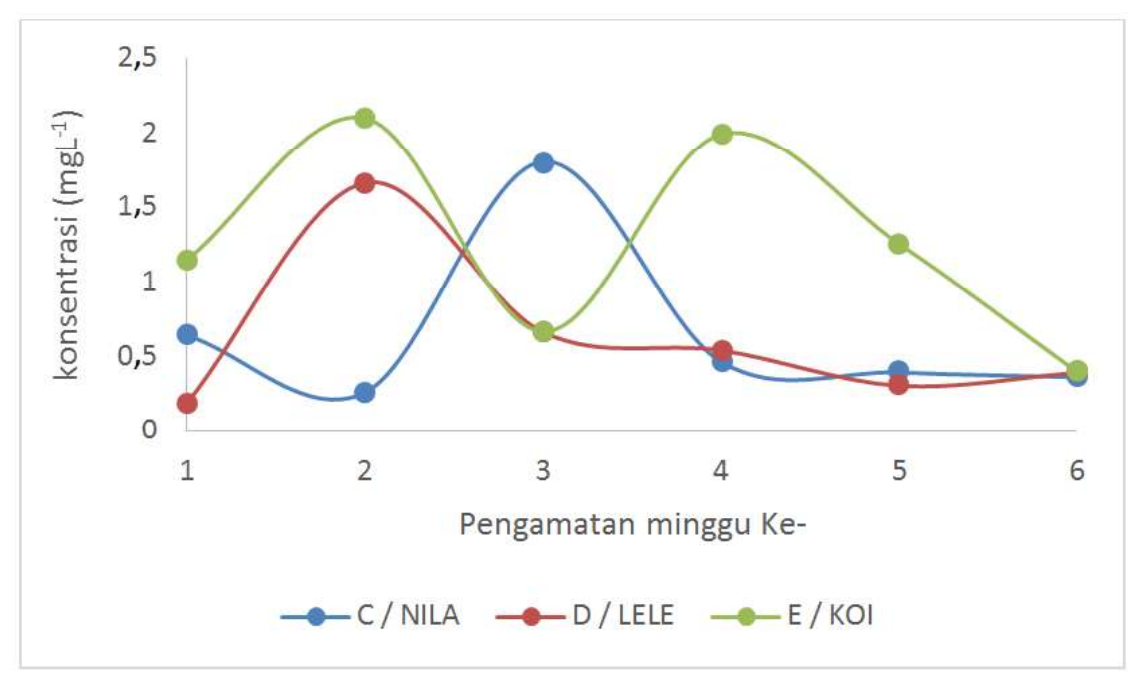

Gambar 4. Konsentrasi nitrat berdasarkan perlakuan dari setiap minggu pengamatan

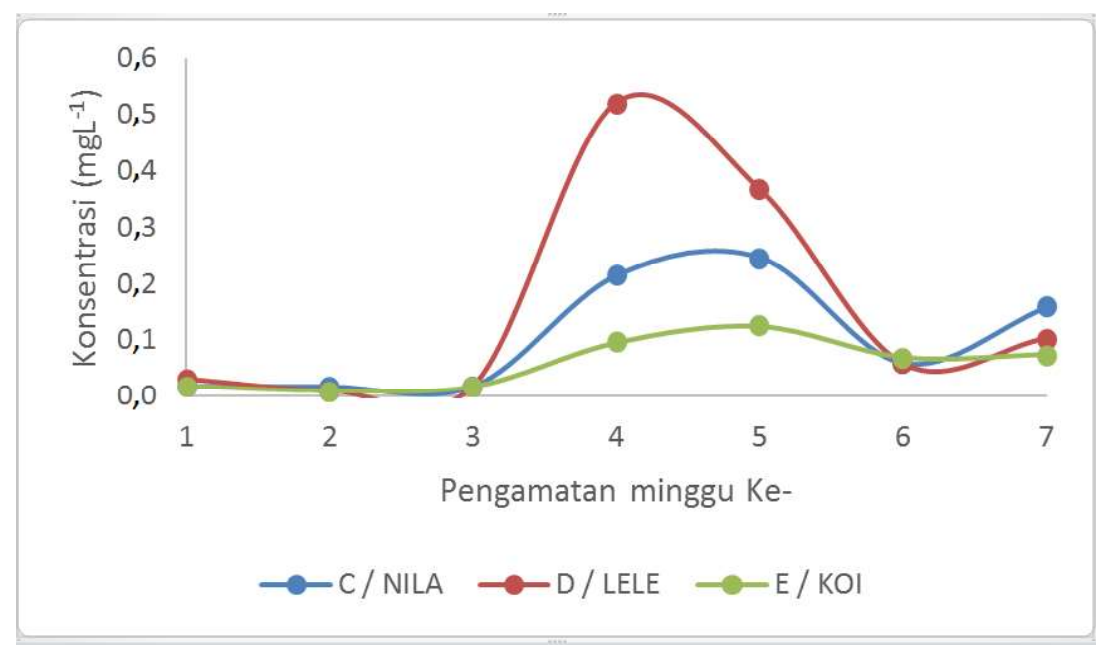

Gambar 5. Konsentrasi amonia berdasarkan perlakuan dari setiap minggu pengamatan

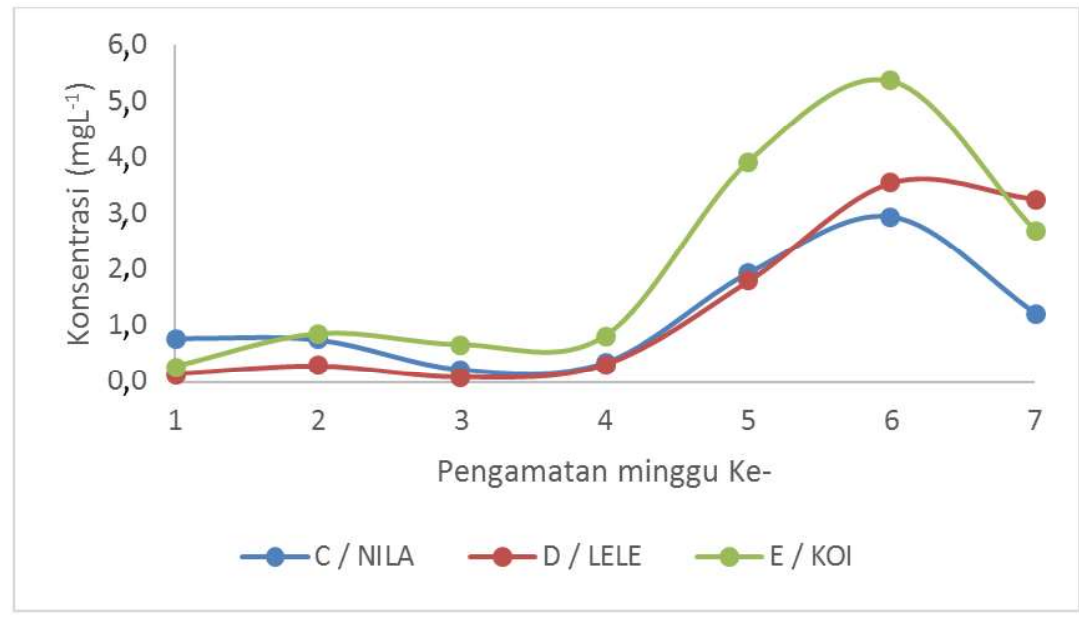

Gambar 6. Konsentrasi fosfat berdasarkan perlakuan dari setiap minggu pengamatan 


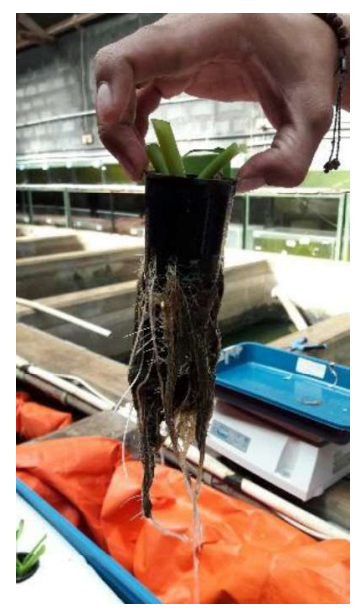

Akar tanaman akuaponik

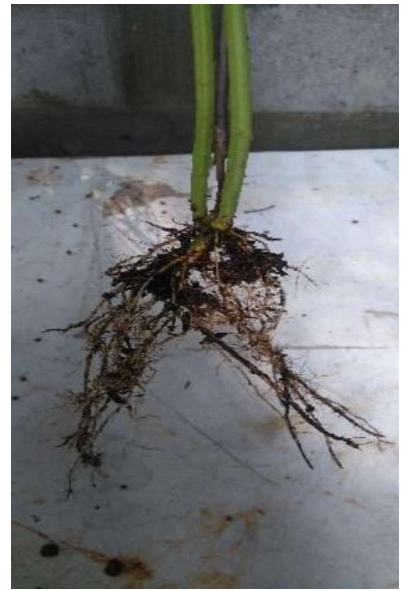

Akar tanaman media kompos

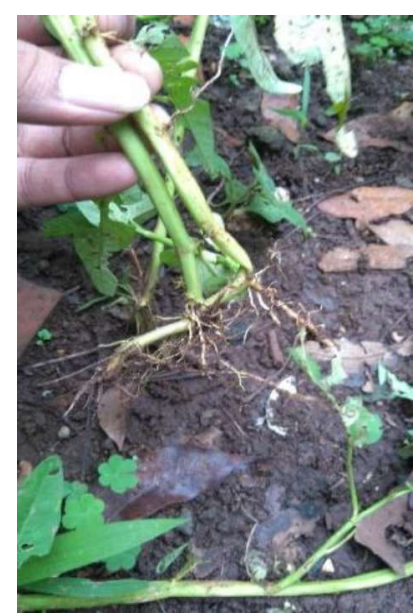

Akar tanaman media tanah

Gambar 7. Perakaran kangkung darat yang ditanam pada akuaponik, kompos, dan media tanah

\section{Pembahasan}

Pertumbuhan bobot lele sebesar 7,8 $\pm 1,18 \mathrm{~g}$ menunjukkan pertumbuhan bobot tertinggi dibandingkan dengan jenis ikan lainnya selama penelitian (Tabel 1), sedangkan pertumbuhan terendah terdapat pada koi sebesar 4,2 $\pm 0,94$ g. Perbedaan pertumbuhan ini telah terlihat sejak minggu pertama pengamatan (Gambar 1). Pertumbuhan ikan dipengaruhi salah satunya oleh efisiensi pencernaan dan fisiologi usus (Zonneveld et al. 1991). Lele merupakan ikan karnivora yang mempunyai usus lebih pendek dibandingkan dengan ikan herbivora dan omnivora. Hal ini pada gilirannya berpengaruh pada proses pencernaan yang semakin cepat dalam penyerapan makanan namun banyak pakan yang terbuang, baik dari sisa pakan ataupun feses. Hal itu sesuai dengan pernyataan Arief et al. (2014) bahwa efisiensi pakan pada lele berkisar 30-53\%. Hal sebaliknya terlihat pada nila dan koi yang merupakan ikan herbivora (ikan pemakan tumbuhan), memiliki efisiensi pencernaan makanan lebih baik yaitu > $80 \%$ dibandingkan dengan ikan karnivora (Mulyani et al. 2014, Iskandar \& Elrifadah 2015).
Pertumbuhan tanaman kangkung baik pertambahan panjang batang dan pertambahan helai daun, maupun bobot (Gambar 2 dan 3, Tabel 2) menunjukkan pertumbuhan tanaman kangkung pada akuaponik lebih tinggi dibandingkan dengan kontrol positif (dengan media kompos, perlakuan A) maupun kontrol negatif (dengan media tanah tanpa kompos, perlakuan B). Hal itu dikarenakan nutrien yang berasal dari feses dan sisa pakan ikan mudah terurai menjadi nutrien anorganik da-lam air dan lebih cepat diserap tanaman. Terlihat dari hasil pengamatan (Gambar 4, 5, dan 6), terjadi peningkatan konsentrasi nitrat, ammonia dan fosfat dan kembali pada minggu ke 3 dan ke 4. Hal itu menunjukkan adanya penyerapan unsur hara oleh tanaman kangkung. Semakin banyak dan besar tanaman yang digunakan pada budi daya akuaponik semakin efektif dalam mereduksi amonia, penggunaan 30 batang per rumpun kangkung dapat mengurangi amonia hingga 58,57 $\mathrm{mg} \mathrm{L}^{-1}$ (Dauhan et al. 2014).

Pertumbuhan panjang batang kangkung sebagaimana terlihat pada Gambar 2 dan Tabel 2, menunjukkan budi daya akuaponik mampu mem- 
percepat pertumbuhan tanaman kangkung. Tinggi batang kangkung pada saat panen pada kombinasi dengan ketiga jenis ikan hanya memperlihatkan sedikit perbedaan, yaitu berkisar antara 78,5 $\pm 10,93$ sampai dengan $81,1 \pm 15,28 \mathrm{~cm}$, dan semuanya lebih tinggi dibandingkan dengan kontrol positif yang hanya mencapai $53,7 \pm 5,56 \mathrm{~cm}$ dan kontrol negatif sebesar 43,6 $\pm 7,52 \mathrm{~cm}$. Hal tersebut menunjukkan bahwa sistem akuaponik dapat meningkatkan produktivitas tanaman dan efektivitas penyerapan nutrien.

Pertambahan jumlah helai daun kangkung (Gambar 3 dan Tabel 2) pada akuaponik dengan koi dan dengan nila memiliki jumlah yang tidak jauh berbeda, sedangkan yang dipelihara bersama lele hanya menghasilkan jumlah daun yang lebih sedikit. Namun demikian ketiganya memiliki jumlah rata-rata helai daun diatas jumlah ratarata helai daun kangkung pada pemeliharan media kompos dan tanah. Hal ini dikarenakan nutrisi dalam bentuk nitrat dan fosfat yang diserap oleh tanaman pada sistem akuaponik lebih tinggi dibandingkan tanaman yang ditanam pada media kompos dan tanah. Tingginya nitrogen dan fosfor yang diserap oleh tanaman pada sistem akuaponik dibuktikan dengan kondisi perakaran tanaman kangkung yang lebih banyak dibandingkan dengan yang bukan akuaponik (Gambar 7). Berdasarkan pembahasan tersebut kombinasi ikan lele dengan kangkung direkomendasikan untuk diintegrasikan dalam budi daya akuaponik.

Sumber nitrogen yang terdapat dalam kompos dan tanah yang diberi pupuk pada awal penanaman, makin lama makin tidak mencukupi kebutuhan tanaman, sementara itu pada sistem akuaponik nutrien tercukupi sepanjang waktu (Setijaningsih \& Umar 2015, Setijaningsih \& Suryaningsih 2015). Hal ini sesuai dengan pernyataan Doorenbos \& Pruitt (1977), yang menyatakan bahwa tanaman hanya dapat tumbuh opti- mal dan memberikan hasil yang tinggi bila kebutuhan airnya dapat dipenuhi dalam jumlah dan waktu yang tepat.

Biomassa panen tanaman kangkung tertinggi diperoleh pada akuaponik bersama ikan koi (Tabel 2). Hal itu terjadi karena ikan koi merupakan ikan jenis herbivora dengan penyerapan makanan lebih lambat sehingga banyak pakan yang tidak termakan dan tersirkulasi pada tanaman kangkung. Hal tersebut terlihat pula pada konsentrasi nitrat dan fosfat pada akuaponik kangkung bersama koi yang lebih tinggi dibandingkan dua jenis ikan yang lain (Gambar 3).

\section{Simpulan}

Kesimpulan yang dapat ditarik dari penelitian ini adalah pada budi daya akuaponik ikan bersama kangkung, ikan lele menunjukkan pertumbuhan tertinggi dibandingkan ikan nila dan koi, sedangkan pertumbuhan tanaman kangkung tertinggi diperoleh pada akuaponik koi dengan kangkung .

\section{Persantunan}

Penelitian dibiaya melalui hibah skim ALG (Academic Leadership Grant) Universitas Padjadjaran tahun 2015, untuk itu penulis mengucapkan terima kasih kepada Rektor Universitas Padjadjaran.

\section{Daftar pustaka}

Arief M, Fitriani N, Subekti S. 2014. Pengaruh pemberian probiotik berbeda pada pakan komersial terhadap pertumbuhan dan efisiensi pakan ikan lele sangkuriang (Clarias sp). Jurnal Ilmiah Perikanan dan Kelautan, 6(1): 49-53.

Crab R, Avnimelech Y, Defoirdt T, Bossier P, Verstraete W. 2007. Nitrogen removal techniques in aquaculture for a sustainable production. Aquaculture, 270(1): 1-14.

Dauhan RES, Efendi E, Suparmono. 2014. Efektivitas sistem akuaponik dalam mereduksi 
konsentrasi amonia pada sistem budidaya ikan. Jurnal Rekayasa dan Teknologi Budidaya Perairan, 3(1): 297-301.

Diver S. 2006. Aquaponics-integration of hydroponics with aquaculture. National Sustainable Agriculture Information Service. Australia. $28 \mathrm{p}$.

Djokosetiyanto D, Sunarma A, Widanarni. 2006. Perubahan ammonia $(\mathrm{NH} 3-\mathrm{N})$, nitrit (NO2N) dan nitrat (NO3-N) pada media pemeliharaan ikan nila merah (Oreochromis sp.) di dalam sistem resirkulasi. Jurnal Akuakultur Indonesia, 5(1): 13-20.

Doorenbos J, Pruitt WO. 1977. Crop water requirements. Irrigation and Drainage Paper No. 24. Food and Agriculture Organization. of the United Nations Rome.

ECOLIFE Foundation. 2011. Introduction to village aquaponics. ECOLIFE. 324 State Place. Escondido. 25 p.

Endut A, Juson. A., Nusron A, Hassan. A. 2009. Effect of flow rate on water quality parameters and plant growth of water spinach (Ipomoea aquatica) in an aquaponic recirculating system. Desalination and Water Treatment. Desalination Publication. 5(1-3): 1928.

Fujaya Y. 2004. Fisiologi Ikan: Dasar Pengembangan Teknik Perikanan. Rineka Cipta. Jakarta. $179 \mathrm{hlm}$.

Garno YS. 2002. Beban pencemaran limbah perikanan budidaya dan yutrofikasi di perairan waduk di DAS Citarum. Jurnal Teknologi Lingkungan. 3(2): 112-120.

Hastuti S, Subandiono. 2014. Performa produksi ikan lele dumbo (Clarias gariepinus, Burch) yang dipelihara dengan teknologi biofloc. Indonesian Journal of Fisheries Science and Technology, 10(1): 37-42.

Huisman EA. 1976. Food conversion efficiencies at maintenance and production level carp Cyprinus carpio L. and rainbow trout Salmo gairdneri. Aquaculture, 9(2): 259-273.

Ihsanudin I, Rezeki S, Yuniarti T. 2014. Pengaruh pemberian rekombinan hormon pertumbuhan $(r G H)$ melalui metode oral dengan interval waktu yang berbeda terhadap pertumbuhan dan kelulusan hidup benih ikan nila larasati (Oreochromis niloticus). Jurnal of Aquaculture Management and Technology, 3(2): 94-102.
Iskandar R, Elrifadah. 2015. Pertumbuhan dan efisiensi pakan ikan nila (Oreochromis niloticus) yang diberi pakan buatan berbasis kiambang. Ziraa'ah, 40(1): 18-24.

Mulyani YS, Yulisman, Fitrani M. 2014. Pertumbuhan dan efisiensi pakan ikan nila (Oreochromis niloticus) yang dipuasakan secara periodik. Jurnal Akuakultur Rawa Indonesia, 2(1): 1-12.

Nelson RL. 2008. Aquaponic Equipment: The Biofilter. http://www.aquaponicsjournal. com/ docs/Aquaponic-Equipment-The-Bio Filter.pdf. (Diunduh 16 Mei 2016).

Ogunji JO, Kloas W, Wirth M, Schulz C, Rennert B. 2008. Housefly maggot meal (magmeal) as a protein source for Oreochromis niloticus (Linn.). Asian Fisheries Science, 21(3): 319-331

Rakocy JE, Masse MP, Losordo TM. 2006. Recirculating aquaculture tank production systems: Aquaponics- integrating fish and plant culture, Publication No. 454. Southern Regional Aquaculture Center, United States of Agriculture, USA. $16 \mathrm{p}$.

Setijaningsih L, Suryaningsih LH. 2015. Pemanfaatan limbah budidaya ikan lele (Clarias bacrachus) untuk ikan nila (Oreochromis niloticus) dengan sistem reskulasi. Jurnal Ilmu-ilmu Hayati, 14(3): 287-293.

Setijaningsih L, Umar C. 2015. Pengaruh retensi air terhadap pertumbuhan ikan nila (Oreochromis niloticus) pada budidaya sistem akuaponik dengan tanaman kangkung. Jurnal Ilmu-ilmu Hayati, 14(3): 267-275.

Sulawesty F, Chrismadha T, Mulyana E. 2014. Laju pertumbuhan ikan mas (Cyprinus carpio) dengan pemberian pakan lemna (lemna perpusilla) segar pada kolam sistem aliran tertutup. Limnotek, 21(2): 177-184.

Susila N. 2015. Dampak pencemaran air sungai kahayan pada usaha budidaya ikan kahanda di Kelurahan Pahandut Seberang Kota Palangka Raya. Jurnal Ilmu Hewani Tropika, 4(2): 71-74.

Utomo NBP, Hasanah P, Mokoginta I. 2005. Pengaruh cara pemberian pakan yang berbeda terhadap konversi pakan dan pertumbuhan ikan mas (Cyprinus carpio) di karamba jaring apung. Jurnal Akuakultur Indonesia, 4(2): 49-52.

Yosmaniar. 2010. Hubungan konversi pakan dengan beban limbah hara $\mathrm{N}$ dan $\mathrm{P}$ yang dibu- 
ang ke air pemeliharaan. In: Sudrajat A (ed.). Technological Innovation of Aquaculture in Indonesia. Balai Riset Perikanan Budidaya Air Tawar. Bogor. pp. 681-688.
Zonneveld N, Huisman EA, Boon JN. 1991. Prinsip-prinsip Budi Daya Ikan. PT Gramedia Pustaka Utama, Jakarta. 318 hlm. 